\begin{tabular}{|c|c|c|c|c|c|c|}
\hline \multirow{2}{*}{\multicolumn{2}{|c|}{$\begin{array}{l}\text { Disease Activity } \\
\text { Assessment }\end{array}$}} & \multicolumn{4}{|c|}{ RAPID-3 } & \multirow[b]{2}{*}{ Kappa } \\
\hline & & $\begin{array}{c}\text { Remission } \\
\leq 3\end{array}$ & $\begin{array}{l}\text { LOWDA } \\
>3-\leq 6\end{array}$ & $\begin{array}{l}\text { ModDA } \\
>6-\leq 12\end{array}$ & $\begin{array}{c}\text { HighDA } \\
>12\end{array}$ & \\
\hline \multicolumn{7}{|c|}{ DAPSA } \\
\hline 疎 & $\begin{array}{l}\text { Remission } \\
\text { LowDA } \\
\text { ModDA } \\
\text { HighDA }\end{array}$ & $\begin{array}{c}29(20.9) \\
15(10.8) \\
6(4.3) \\
4(2.9)\end{array}$ & $\begin{array}{l}3(2.2) \\
11(7.9) \\
8(5.8) \\
4(2.9)\end{array}$ & $\begin{array}{c}1(0.7) \\
6(4.3) \\
17(12.2) \\
12(8.6)\end{array}$ & $\begin{array}{c}0 \\
1(0.7) \\
4(2.9) \\
18(12.9)\end{array}$ & $\begin{array}{l}0.388^{\prime \prime} \\
0.572^{b}\end{array}$ \\
\hline $\begin{array}{l}\frac{8}{8} \\
\frac{\pi}{a}\end{array}$ & $\begin{array}{l}\text { Remission } \\
\text { LowDA } \\
\text { ModDA } \\
\text { HighDA }\end{array}$ & $\begin{array}{l}4(2.8) \\
5(3.4) \\
1(0.7) \\
1(0.7)\end{array}$ & $\begin{array}{c}0 \\
3(2.1) \\
7(4.8) \\
4(2.8)\end{array}$ & $\begin{array}{c}0 \\
5(3.4) \\
16(11) \\
29(20)\end{array}$ & $\begin{array}{c}0 \\
1(0.7) \\
9(6.2) \\
60(41.4)\end{array}$ & $\begin{array}{l}0.284^{2} \\
0.484^{b}\end{array}$ \\
\hline \multicolumn{7}{|c|}{ Minimal Disease Activity } \\
\hline 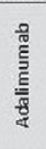 & $\begin{array}{c}\text { MDA } \\
\text { Yes } \\
\text { No } \\
\text { VLDA } \\
\text { Yes } \\
\text { No }\end{array}$ & $\begin{array}{c}45(32.1) \\
9(6.4) \\
11(15.3) \\
17(23.6)\end{array}$ & $\begin{array}{c}5(3.6) \\
21(15) \\
0 \\
12(16.7)\end{array}$ & $\begin{array}{c}1(0.7) \\
36(25.7) \\
0 \\
17(23.6)\end{array}$ & $\begin{array}{c}0 \\
23\{16.4\} \\
0 \\
15\{20.8\}\end{array}$ & $0.574^{c}$ \\
\hline $\begin{array}{l}\frac{8}{0} \\
\frac{\pi}{2}\end{array}$ & $\begin{array}{c}\text { MDA } \\
\text { Yes } \\
\text { No } \\
\text { VLDA } \\
\text { Yes } \\
\text { No }\end{array}$ & $\begin{array}{l}7(4.8) \\
4(2.8) \\
\\
1(1.4) \\
7(10.1)\end{array}$ & $\begin{array}{c}0 \\
14(9.7) \\
0 \\
0 \\
5(7.2)\end{array}$ & $\begin{array}{c}0 \\
50(34.5) \\
0 \\
17(24.6)\end{array}$ & $\begin{array}{c}0 \\
70(48.3) \\
0 \\
39(56.5)\end{array}$ & $0.119^{c}$ \\
\hline $\begin{array}{l}\text { All val } \\
\text { 'Kapp } \\
\text { DAPSA } \\
\text { "Kapp } \\
\text { activit } \\
\text { 'Kapp } \\
\text { activit } \\
\text { activit } \\
\text { DAPA } \\
\text { Minim } \\
\text { enthes } \\
\text { RAPID } \\
\text { minim } \\
\text { activit }\end{array}$ & $\begin{array}{l}\text { are } n(\%) \text {, unle } \\
\text { reem ent betw } \\
\text { reement betw } \\
\text { teg ories of the } \\
\text { reement betw } \\
\text { teg ories of the } \\
\text { sease activitys } \\
\text { lise ase activity } \\
\text { points } \leq 1 \\
\text { routine assessn } \\
\text { lise ase activity, } \\
\text { LDA, very low }\end{array}$ & $\begin{array}{l}\text { wise indicatec } \\
\text { numbers of } p= \\
\text { numbers of } p a \\
\text { and the DAP } \\
\text { umbers of } p a \\
\text { and achiever } \\
\text { mission, } \leq 4 ; \text {;o } \\
T J C \leq 1 \text {, SJC } \leq 1 \\
\text { atient index } \\
\text { low dise ase a } \\
\text { tivity. }\end{array}$ & $\begin{array}{l}\text { ts across the } \\
\text { ts in the ren } \\
\text { ts in the ren } \\
t \text { (yes/no) of } \\
\text { A, S14; Mod } \\
\text { SI S1; patier } \\
\text { DAPSA, dis } \\
\text { ty, ModDA, }\end{array}$ & $\begin{array}{l}\text { ease activity } \\
\text { on + LowDA } \\
\text { on + LowDA } \\
\text { MDA) or } 7 \text { of } \\
\leq 28 \text {; HighDA } \\
\text { in } \leq 15 \text {; patie } \\
\text { activity inde }\end{array}$ & $\begin{array}{l}\text { ModDA + Hi } \\
\text { ModDA + Hit } \\
\text { LDA) criteria } \\
8 . \\
\text { lobal } \leq 20 ; H A \\
\text { psoriatic art }\end{array}$ & $\begin{array}{l}\text { - } 3 \text { and the } \\
\text { ise ase } \\
\text { isease } \\
\text { imal disease } \\
0.5 \text {; tender } \\
\text { MDA, } \\
\text { dise ase }\end{array}$ \\
\hline
\end{tabular}

design, data collection, analysis, interpretation, and abstract writing, review, and approval. Medical writing: Ben Wolfe of AbbVie.

Disclosure of Interest: P. Mease Grant/research support from: AbbVie, Amgen, Bristol Myers, Celgene, Genentech, Janssen, Lilly, Merck, Novartis, Pfizer, Sun Pharma, and UCB, Consultant for: AbbVie, Amgen, Bristol Myers, Celgene, Genentech, Janssen, Lilly, Merck, Novartis, Pfizer, Sun Pharma, and UCB, Speakers bureau: AbbVie, Amgen, Bristol Myers, Celgene, Genentech, Janssen, Lilly, Merck, Novartis, Pfizer, Sun Pharma, and UCB, S. Chen Shareholder of: AbbVie, Inc., Employee of: AbbVie, Inc., F. Ganz Shareholder of: AbbVie, Inc., Employee of: AbbVie, Inc., W. Tillett Grant/research support from: AbbVie, Celgene, Novartis, Pfizer, and UCB, Consultant for: AbbVie, Celgene, Novartis, Pfizer, and UCB, Speakers bureau: AbbVie, Celgene, Novartis, Pfizer, and UCB DOI: 10.1136/annrheumdis-2017-eular.1952

\section{FRI0511 SECUKINUMAB DEMONSTRATES CONSISTENT SAFETY OVER LONG-TERM EXPOSURE IN PATIENTS WITH PSORIATIC ARTHRITIS AND MODERATE-TO-SEVERE PLAQUE PSORIASIS: UPDATED POOLED SAFETY ANALYSES}

P.J. Mease ${ }^{1}$, I.B. Mclnnes ${ }^{2}$, K. Reich ${ }^{3}$, P. Nash ${ }^{4}$, M. Andersson ${ }^{5}$, K. Abrams ${ }^{6}$, L. Pricorp ${ }^{6}$, T. Fox ${ }^{5} .{ }^{1}$ Swedish Medical Center and University of Washington, Seattle, United States; ${ }^{2}$ University of Glasgow, Glasgow, United Kingdom; ${ }^{3}$ Dermatologikum Hamburg and Georg-August-University Göttingen, Hamburg, Germany; ${ }^{4}$ University of Queensland, St Lucia, Australia; ${ }^{5}$ Novartis Pharma AG, Basel, Switzerland; ${ }^{6}$ Novartis Pharmaceuticals Corp., East Hanover, United States

Background: Pooled safety data from secukinumab psoriasis ( $\mathrm{PsO}$ ) and psoriatic arthritis (PsA) clinical trial programs after $\sim 1$ year of exposure have been reported. ${ }^{1,2}$

Objectives: To report updated longer-term secukinumab exposure safety data from PsO and PsA studies (data cut-off: 25 June 2016).

Methods: The PsO data pool consisted of 9 Phase III studies in moderate-tosevere plaque PsO and PsA pool consisted of 3 Phase III studies in active PsA. Secukinumab doses differed in the studies and included intravenous (up to 10 $\mathrm{mg} / \mathrm{kg}$ ) or subcutaneous (s.c.; 75-300 mg) loading, followed by s.c. maintenance dosing (300, 150 or $75 \mathrm{mg}$ ). Placebo patients were re-randomised to secukinumab at 12-24 weeks depending on study design. Only data for approved secukinumab 300 and $150 \mathrm{mg}$ doses were included in analysis. Exposure adjusted incident rates (EAIR) were used to adjust for differences in exposure.

Results: In both PsO and PsA, the most frequently reported adverse events (AEs) with secukinumab were non-serious infections of the upper respiratory tract, headache and arthralgia (Table). The EAIRs of AEs of special interest with secukinumab including Crohn's disease, Candida infections, serious infections, inflammatory bowel disease, major adverse cardiac events and neutropenia (reported in the Table) were similar in both PSO and PsA indications, and comparable to those reported previously. ${ }^{1,2}$ No cases of tuberculosis (new onset or reactivation) were reported.
Table 1. Summary of pooled safety of secukinumab in PSO and PsA

\begin{tabular}{lcc}
\hline & $\begin{array}{c}\text { PSO } \\
\text { Any secukinumab } \\
\mathrm{N}=3893\end{array}$ & $\begin{array}{c}\text { PsA } \\
\text { Any secukinumab } \\
\mathrm{N}=1128\end{array}$ \\
\hline Total exposure, patient-years ) & 7769.0 & 1907.0 \\
Min-max exposure (days) & $1-1526$ & $16-1464$ \\
Death, $\mathrm{n}(\%)$ & $7(0.2)$ & $4(0.4)$ \\
AE's by EAIR: AE per 100 Pt-years $(95 \% \mathrm{Cl})$ & & \\
$\quad$ Any AE & $196.9(190.3,203.6)$ & $173.7(162.5,185.5)$ \\
$\quad$ Any serious AE & $7.2(6.6,7.8)$ & $8.5(7.2,10.0)$ \\
Frequent AEs ${ }^{1}$ & & \\
$\quad$ Nasopharyngitis & $18.2(17.1,19.3)$ & $13.7(12.0,15.7)$ \\
$\quad$ Headache & $6.3(5.7,6.9)$ & $4.8(3.9,5.9)$ \\
$\quad$ Upper respiratory tract infections & $6.2(5.6,6.8)$ & $11.2(9.6,12.9)$ \\
$\quad$ Arthralgia & $5.1(4.6,5.6)$ & $4.3(3.4,5.3)$ \\
AEs of special interest & & \\
$\quad$ Candida infections & $2.1(1.8,2.4)$ & $2.3(1.6,3.1)$ \\
$\quad$ Serious infections & $1.4(1.2,1.7)$ & $1.8(1.3,2.5)$ \\
Inflammatory Bowel Disease & $0.3(0.2,0.4)$ & $0.5(0.2,0.9)$ \\
Crohn's disease & $0.1(0.0,0.1)$ & 0 \\
Ulcerative colitis & $0.2(0.1,0.3)$ & $0.1(0.0,0.4)$ \\
MACE & $0.3(0.2,0.5)$ & $0.3(0.1,0.6)$ \\
Neutropenia & $0.4(0.3,0.5)$ & $0.7(0.4,1.2)$ \\
\hline
\end{tabular}

${ }^{1}$ Adverse events in the secukinumab group that occurred with an IR $>5.0$ during the entire safety period in either of the spooled groups; AE, adverse event; EAIR, exposure adjusted incidence rate per 100 patient-years; MACE, major adverse cardiac event; N, number of patients in the analysis.

Conclusions: The safety profile of secukinumab was similar for PsO and PsA patients supporting its long-term use in these chronic conditions. Secukinumab long-term exposure safety data is consistent with that previously reported with shorter-term exposure, including being well tolerated, and without any new safety signals identified.

References:

[1] Van de Kerkhof PC, et al. J Am Acad Dermatol 2016;75:83-98.

[2] Mease PJ, et al. Arthritis Rheumatol 2015; 67:A2886.

Disclosure of Interest: P. Mease Grant/research support from: AbbVie, Amgen, Biogen Idec, BMS, Celgene, Crescendo, Janssen, Lilly, Merck, Novartis, Pfizer, and UCB, Consultant for: AbbVie, Amgen, Biogen Idec, BMS, Celgene, Covagen, Crescendo, Janssen, Lilly, Merck, Novartis, Pfizer, UCB, Speakers bureau: AbbVie, Amgen, Biogen Idec, BMS, Crescendo, Janssen, Lilly, Pfizer, and UCB, I. McInnes Grant/research support from: AbbVie, Amgen, BMS, Celgene, Janssen, Lilly, Novartis, Pfizer, and UCB, Consultant for: AbbVie, Amgen, BMS, Celgene, Janssen, Lilly, Novartis, Pfizer, and UCB, Speakers bureau: AbbVie, Amgen, BMS, Celgene, Janssen, Lilly, Novartis, Pfizer, and UCB, K. Reich Grant/research support from: AbbVie, Amgen, Biogen, Boehringer Ingelheim Pharma, Celgene, Centocor, Covagen, Forward Pharma, GlaxoSmithKline, Janssen-Cliag, Leo, Lilly, Medac, Merck Sharp and Dohme Corp., Novartis, Ocean Pharma, Pfizer, Regeneron, Takeda, UCB Pharma, Xenoport, Speakers bureau: AbbVie, Amgen, Biogen, Boehringer Ingelheim Pharma, Celgene, Centocor, Covagen, Forward Pharma, GlaxoSmithKline, Janssen-Cliag, Leo, Lilly, Medac, Merck Sharp and Dohme Corp., Novartis, Ocean Pharma, Pfizer, Regeneron, Takeda, UCB Pharma, Xenoport, P. Nash Grant/research support from: AbbVie, Amgen, BMS, Celgene, Eli Lilly, Hospira, MSD, Pfizer, Janssen, UCB, Novartis, Roche; Consultancy fees: AbbVie, Amgen, BMS, Celgene, Eli Lilly, Hospira, MSD, Pfizer, Janssen, UCB, Novartis, Roche, Speakers bureau: AbbVie, Amgen, BMS, Celgene, Eli Lilly, Hospira, MSD, Pfizer, Janssen, UCB, Novartis, Roche, M. Andersson Employee of: Novartis, K. Abrams Shareholder of: Novartis, Employee of: Novartis, L. Pricorp Shareholder of: Novartis, Employee of: Novartis, T. Fox Shareholder of: Novartis, Employee of: Novartis

DOI: 10.1136/annrheumdis-2017-eular.4991

\section{FRI0512 APREMILAST, AN ORAL PHOSPHODIESTERASE 4 INHIBITOR, IS ASSOCIATED WITH LONG-TERM (156-WEEK) IMPROVEMENTS IN BASDAI IN PSORIATIC ARTHRITIS PATIENTS: POOLED RESULTS FROM 3 PHASE III, RANDOMIZED, CONTROLLED TRIALS}

P.J. Mease ${ }^{1}$, H. Marzo-Ortega ${ }^{2}$, A. Poder ${ }^{3}$, F. Van den Bosch ${ }^{4}$, J. Wollenhaupt ${ }^{5}$, E. Lespessailles ${ }^{6}$, M. Mcllraith ${ }^{7}$, L. Teng ${ }^{7}$, S. Hall ${ }^{8} .{ }^{1}$ Swedish Medical Center and University of Washington School of Medicine, Seattle, United States: ${ }^{2}$ NIHR Leeds Musculoskeletal Biomedical Research Unit, Leeds Teaching Hospitals and University of Leeds, Leeds, United Kingdom; ${ }^{3}$ Clinical Research Centre Ltd, Tartu, Estonia; ${ }^{4}$ UZ Gent, Gent, Belgium; ${ }^{5}$ Schön Klinik Hamburg Eilbek, Hamburg, Germany; ${ }^{6}$ University of Orléans, Orléans, France; ${ }^{7}$ Celgene Corporation, Summit, United States; ${ }^{8}$ Monash University, CabriniHealth, Melbourne, Australia

Background: In PALACE psoriatic arthritis (PSA) studies, the Bath Ankylosing Spondylitis Disease Activity Index score (BASDAl) was used as an exploratory measure in a subset of patients (pts) considered by investigators to have axial involvement, although PSA spondylitis was not confirmed by imaging.

Objectives: Report the impact of apremilast $30 \mathrm{mg}$ BID (APR) treatment on BASDAl over 156 wks using pooled PALACE 1-3 data of pts with active PsA despite prior conventional DMARDs and/or biologics. 